\title{
The Effect of Blood Groups on Infection and Prognosis of SARS- CoV-2
}

\section{Kan Gruplarının SARS-CoV-2 Enfeksiyonu ve Prognozu Üzerine Etkisi}

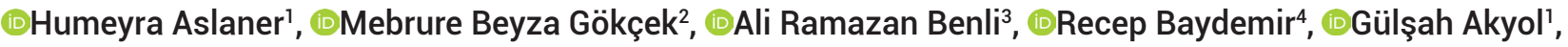

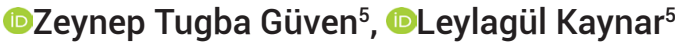

'Kayseri City Hospital, Clinic of Family Medicine, Kayseri Turkey

${ }^{2}$ Kayseri Provincial Health Directorate, Clinic of Family Medicine, Kayseri, Turkey

${ }^{3}$ Karabuk University, Faculty of Medicine, Clinic of Family Medicine Karabük, Turkey

${ }^{4}$ Erciyes University, Faculty of Medicine, Department of Neurology, Kayseri, Turkey

${ }^{5}$ Erciyes University, Faculty of Medicine, Department of Hematology, Kayseri, Turkey

Copyright@Author(s) - Available online at www.dergipark.org.tr/tr/pub/medr

Content of this journal is licensed under a Creative Commons Attribution-NonCommercial 4.0 International License.

\begin{abstract}
Aim: This study aimed to investigate the effect of blood groups on the risk and prognosis of severe acute respiratory syndrome coronavirus 2 (SARS-CoV-2) in the infected/source cases and contact individuals.

Material and Method: This study was designed as a descriptive and retrospective study. The individuals who were in contact with the SARS-CoV-2main/source cases and followed at home were included in the study. The distribution of the participants according to their blood groups was assessed. Patients were divided into three groups as group 1 including source/main cases, group 2 including SARS$\mathrm{CoV}$-2contacts who were living in the same house with the source case and followed up, and group 3 including contacts who were followed up in the same house but did not develop SARS-CoV-2 during the follow-up.

Results: While the rate of Non-O blood group was the highest $(n=365,39.4 \%)$ in group 2the rate of 0 blood group was the highest $(n=190,42.8 \%)$ in group 3 (p:0.028). While the rate of Rh positive blood group was high in group 1 that of Rh negative blood group was higher in group 3 (p:0.000). For other variables, the presence of a chronic disease was more in group 1 (p:0.000). Rh (+) blood group (OR:0.464, p:0.010, \%95 Cl: $0.306 \sim 0.703$ ) was among the factors affecting the development of the infection.

Conclusion: Patients infected with SARS-CoV-2 mostly had A, Non-O blood group and Rh positivity. Having Rh (+) blood group may have increased the rate of infection development in high-risk household contacts. After patients in this blood group were detected as contacts a closer follow-up may be necessary to decrease morbidity.
\end{abstract}

Keywords: SARS-COV-2; ABO and Rh blood group; comorbid diseases

Öz

Amaç: Bu çalışmanın amacı, asıl/kaynak vakalar ve temaslı olan vakalarda kan gruplarının Ciddi Akut Solunum Yolu Sendromu 2 (SARS-CoV-2) riskini ve prognozu nasıl etkilediğini araştırmaktır.

Materyal ve Metot: Çalışmamız tanımlayıcı retrospektif olarak planlanmıştır. SARS-CoV-2 bulunan asıl/kaynak vakalar ile temaslı olup evde takip edilen bireyler dahil edilmiştir. Katılımcıların kan gruplarına göre dağılımları incelenmiştir. Hastalar 1.grup, kaynak/asıl vakalardan, 2.grup ev içi temaslı olup karantina sürecinde SARS-CoV-2 olan hastalar, 3.grup ev içi temaslı olup karantina sürecinde SARS-CoV-2 gelişmeyen bireyler olarak üç gruba ayrıldı.

Bulgular. Çalışmaya 1451 kişi dâhil edilmiştir. Yaş ortancası 41 idi. Gruplar arasında ABO kan grupları açısından fark yoktu ama A kan grubu 1. Grupta (\% 45.4) en fazla orandaydı (p:0.61). Non-O kan grubu 2.grupta (\%39.4) en fazla iken, 0 kan grubu da 3.grupta (\%42.8) en fazla idi (p: 0.028). Rh pozitif kan grubu 1. grupta fazla idi. Rh negatif kan grubu 3. grupta daha fazla idi (p:0.000). Rh (+) kan grubu (OR:0.464, p: 0.010 \%95 Cl: $0.306 ~ 0.703$ ) ev içi temaslı olan vakalarda takipte enfeksiyon gelişmesini etkileyen faktörlerdendi. Sonuç: SARS-CoV-2 ile enfekte olan hastalarda büyük oranda A, Non-O kan grubu ve Rh pozitifliği vardı. Yüksek risk taşıyan ev içi temaslılarda Rh (+) kan grubuna sahip olma enfeksiyon gelişme oranını artırmış olabilir. Bu kan grubundaki hastaların temaslı olduğu tespit edildikten sonra daha yakın takip edilmesi morbiditeyi azaltmak için gerekebilir.

Anahtar Kelimeler : SARS-COV-2;ABO ve Rh kan grubu; komorbid hastalıklar 


\section{INTRODUCTION}

Coronaviruses belonging to the Coronaviridae family are enveloped and non-segmented ribonucleic acid viruses that can cause infective diseases in humans and other mammals (1). They most commonly cause upper respiratory tract infections. Their previous types that caused fatal infections are Severe Acute Respiratory Syndrome-Coronavirus (SARS Co-V) and Middle East Respiratory Syndrome-Coronavirus (MERS Co-V) most commonly $(2,3)$. Cases with a viral pneumonia-like disease of unknown cause were detected in Wuhan, China in December 2019. The virus could be detected as a result of the studies and it took place in literature as severe acute respiratory syndrome coronavirus 2 (SARSCoV-2) (4). Infected patients have had different clinical courses and the infection has been observed to have more severe course especially in people with a chronic disease (5). There is not a biological marker showing the clinical course and severity of the disease yet.

ABO blood groups are genetically coded antigens in structure of glycoprotein present on the surface of erythrocytes. Rh groups are another group of antigens and called positive or negative according to the presence or absence of $D$ antigen (6). It has been revealed that differences in $\mathrm{ABO}$ and $\mathrm{Rh}$ blood groups are effective on clinical course of the disease in cardiovascular, oncologic and some infectious diseases $(7,8)$. For example, it was reported that individuals with 0 blood group were more susceptible to vibrio cholerae and had more severe clinical course (9). Similar studies have been performed for SARS-CoV-2 as well and have revealed that people with A blood group are more susceptible to the infection (10). However, studies on this subject are not sufficient and their number is limited. This study aimed to investigate the effect of ABO, $\mathrm{O}$ and Non-O, and Rh blood groups on the risk and prognosis of severe acute respiratory syndrome coronavirus 2 (SARS-CoV-2) in the infected/source cases and contact individuals.

\section{MATERIAL AND METHOD}

\section{Study design and setting}

This study was designed as a descriptive and retrospective study. Patients who were followed up at 'Erciyes University Faculty of Medicine Hospitals and Secondary Care Public Hospitals' and patients/individuals who were followed up/isolated in their home were included in the study. The case information was obtained by file scanning through the Public Health Management System (PHMS) records of the Turkish Ministry of Health and hospital records. This study consisted of three groups. Group 1 included SARS-CoV-2(+) source patients, group 2 included SARSCoV-2(+) contacts who were living in the same house with the infected patient and followed up, and group 3 included SARS-CoV-2(-) contacts who were living in the same house with the infected patient and followed up. As contacts living in the same house with the infected patient are accepted as high-risk group for SARS-CoV-2infection, they were included in the study. Kin relationships were not preferred and therefore, partners were included in the study. Distributions of the participants according to ABO, $O$ and Non-O, and Rh blood groups were assessed. Presence of a chronic disease, smoking history, being a healthcare worker, being followed up in home or hospitalizations and presence of pneumonia were also assessed.

\section{Study participants}

Individuals at the age of 18 and above (18-100) who were SARS-CoV-2(+), who were SARS-CoV-2(+) contacts and followed up and who were SARS-CoV-2(-) contacts and followed up were analyzed. Data of 1371 patients were obtained. As blood groups of 51 patients and information about the presence of a chronic disease and follow-up status in 29 patients could not be obtained, they were excluded. G*Power 3.1 analysis program was used for power analysis to determine the sample size in this study. Minimum number of the participants for the study was determined as 1,125 ( $\mathrm{a}$ - value:0.05, $\beta$-value:0.80).

Necessary institutional consents were obtained from Kayseri Local Health Authority, Department of Public Health Services. The approval of Erciyes University Medical Faculty Ethics Committee was obtained (Date: 02.12.2020; Decision No: 2020/615) and additionally, Turkish Ministry of Health approval was also obtained on 12th of May 2020 for this study as required.

\section{Statistical Analysis}

Statistical analysis was performed using SPSS 22 for Windows (IBM SPSS Inc., Armonk, NY, USA).In data analysis, frequency, mean, median and standard deviation, and minimum and maximum values were determined as descriptive data. Chi-square test was used in comparison of the categorical data. In numerical data, Mann Whitney $U$ test was used for non-normally distributed groups. Logistic regression analysis was performed. $p<0.05$ was accepted as the statistically significant value.

\section{RESULT}

The study was conducted with 1,371 patients. Of these patients, $576(48 \%)$ female and 795 (52\%) male individuals were included in the study. Median age was 41 (18-91). There were 337 (24.6\%) individuals in group 1, $516(37.6 \%)$ in group 2 and $518(37.8 \%)$ in group 3 . The number of male individuals was $203(60.2 \%)$ in group $1,290(56.20 \%)$ in group 2 and $302(58.30 \%)$ in group 3. Median age was 42 (18-91) in group 1, 41 (18-89) in group 2 and $40(18-87)$ in group 3 . The rate of patients who had a chronic disease was $30 \%$ in the study. The rate of those who had pneumonia (pulmonary involvement) was $26.5 \%$, that of those who were hospitalized was $25.3 \%$ and that of those who had smoking history was $28.2 \%$. Only 97 individuals (7.1\%) were healthcare workers. The rates of blood groups among all participants were $42.7 \%$ for $A, 17.2 \%$ for $B, 7.7 \%$ for $A B$ and $32.4 \%$ for 0 . It was $67.6 \%$ for Non-O blood groups. While $90 \%$ were $\mathrm{Rh}$ 
positive, $10 \%$ were Rh negative. The rate of presence of a comorbid disease was $30 \%$. Total exitus rate in Group 1 and Group 2 was $2.4 \%$. Demographic and clinical data of the groups were given in Table 1.

There was no statistical difference among the groups in terms of $\mathrm{ABO}$ blood groups. The rate of $\mathrm{A}$ blood group was the highest (45.4\%) in group 1 and the rate of 0 blood group was the highest (36.7\%) in group 3 (p:0.61). When the groups were assessed in terms of $O$ and Non- $O$ blood groups while the rate of Non-O blood group was the highest $(39.4 \%)$ in group 2, the rate of 0 blood group was the highest (42.8\%) in group 3 (p:0.028). When the groups were assessed in terms of Rh blood groups while the rate of $\mathrm{Rh}$ positive blood group was the highest (95\%) in group 1 , the rate of $\mathrm{Rh}$ negative blood group was significantly higher (15.30\%) in group 3 (p:0.000) (Table 2).

In this study, $8.1 \%$ of the SARS-CoV-2(+) patients (group 1 and 2) had no symptoms. The most common symptoms were fever in 211 patients (24.7\%), loss of smell in 113 patients (13.7\%) and dyspnea in 88 patients (10.3\%). There was no difference among ABO blood groups in terms of the symptoms (p:0.054). However, the most symptomatic group was 0 blood group (12.4\%). Those in Non-O blood groups were less symptomatic ( $p: 0.071)$. When Rh blood groups were assessed in terms of symptoms, Rh (-) blood group (13.7\%) was more asymptomatic (p:0.001) (Table 3 ).

When pulmonary involvement was assessed, the rate of pneumonia (43\%) was found proportionally higher in A blood group (p:0.801). The rate of the presence of pneumonia was high in Rh positive blood group (43.1\%), but it was not statistically significant (p:0.186). The rate of hospitalization was higher in A blood group (45\%) and it was the lowest in AB blood group (p:0.999). While mortality rate was proportionally higher in A blood group (51.5\%), it was lower in O blood group (30.1\%) (p:0.427). There was no difference between 0 and Non-O blood groups in terms of presence of pneumonia, hospitalization,mortality, presence of a comorbid disease, being a healthcare worker and smoking history. The rates of hospitalization $(70.3 \%)$, mortality $(78.8 \%)$ and presence of a comorbid disease $(68.4 \%)$ were higher in Non-O blood group [(p:0.50), (p:0.51), (p:0.18), (p:0.37) (p:0.13), (p:0.28)]. There was no difference between Rh blood groups in terms of presence of pneumonia, hospitalization,mortality, presence of a comorbid disease, being a healthcare worker, and smoking history [(p:0.18), (p:0.19), (p:0.09), (p:0.31), (p:0.35), (p:0.42)]. The rate of Rh positive patients who were hospitalized (41.1\%) was higher and the rate of presence of pneumonia (43.1\%) and mortality $(4.2 \%)$ was proportionally higher in that blood group.

When 1,034 contacts were assessed, the rate of $\mathrm{A}$ blood group was found proportionally higher in group 2 than in group 3 (p:0.65). The rate of Non-O (52.7\%)blood group was higher in group 2 (p:0.007) and the rate of $\mathrm{Rh}(+)$ blood group (52\%) was higher in group 2 than in group 3 (p:0.000). There was no difference between group 2 and 3 in terms of being a healthcare worker and smoking history (p:0.65 and p:0.376 respectively). While Rh (+) blood group (OR:0.464, p: 0.010, 95\% Cl: $0.306 \sim 0.703$ ) and presence of a comorbid disease (OR:4.57, p: 0.000, $\% 95 \mathrm{Cl}: 3.31 \sim 6.30)$ affected infection development during follow-up among contacts living in the same house with the source patient (Table 4). ABO and $O$ and Non-O blood groups, age, gender, healthcare worker status and smoking were not among the factors affecting infection development ( $\mathrm{p}: 0.53$ and p:0.156 respectively, p:0.957, p:0.477, p:0.141, p:0.476).

\begin{tabular}{|c|c|c|c|c|}
\hline & & Group 1 & Group 2 & Group 3 \\
\hline \multirow[t]{2}{*}{ Gender } & Male & $203(60.2)$ & $290(56.2)$ & $302(58.3)$ \\
\hline & Female & $134(39.8)$ & $226(43.8)$ & $216(41.7)$ \\
\hline Age (Years) & Median(min-max) & $42(18-91)$ & $41(18-89)$ & $40(18-87)$ \\
\hline Comorbid Disease & Yes & $147(43.6)$ & $63(12.2)$ & 201(38.8) \\
\hline Health Worker & Yes & $44(13.1)$ & $20(3.9)$ & $33(6.4)$ \\
\hline Smoking & Yes & $95(28.2)$ & $148(28.7)$ & $143(27.6)$ \\
\hline Pneumonia & Yes & $267(79.2)$ & $97(18.8)$ & - \\
\hline Hospitalization & Yes & $254(75.4)$ & $93(18)$ & - \\
\hline Mortality & Yes & $29(8.6)$ & $4(0.8)$ & - \\
\hline
\end{tabular}


Table 2. Distribution of patients according to blood groups

\begin{tabular}{|c|c|c|c|c|c|c|}
\hline & & Group 1 (337) N (\%) & Group 2 (516) N (\%) & Group 3 (518) N (\%) & Total N (\%) & $P$ value \\
\hline \multirow{4}{*}{$A B O$ group } & A & $153(45.4)$ & $231(44.8)$ & 201 (38.8) & 585 (42.7) & \multirow{4}{*}{0.13} \\
\hline & B & 60 (17.8) & $93(18.0)$ & $83(16)$ & $236(17.2)$ & \\
\hline & 0 & $103(30.6)$ & $151(29.3)$ & $190(36.7)$ & $444(32.4)$ & \\
\hline & $A B$ & $21(6.2)$ & $41(7.9)$ & $44(8.5)$ & $106(7.7)$ & \\
\hline \multirow{2}{*}{0 and Non- 0} & 0 & 103(30.6) & $151(29.3)$ & $190(36.7)$ & $444(32.4)$ & \multirow{2}{*}{0.028} \\
\hline & Non-O & $234(69.4)$ & $365(70.7)$ & $328(63.3)$ & $927(67.6)$ & \\
\hline \multirow{2}{*}{ Rh group } & Positive & 320 (95) & $475(92.1)$ & 439 (84.7) & 1234 (90) & \multirow{2}{*}{0.000} \\
\hline & Negative & $17(5)$ & $41(7.9)$ & 79 (15.3) & 1371(10) & \\
\hline
\end{tabular}

Group 1: Source Case, Group 2: SARS CoV2(+) Contact, Group 3: SARS-CoV2(-) Contact Chi-square test analysis was performed

Table 3. Distribution of symptoms according to blood groups

$\begin{array}{lcccccccc} & \text { A } & \text { B } & \mathbf{0} & \text { AB } & \mathbf{0} & \mathrm{Non}-0 & \mathrm{Rh}(+) & \mathrm{Rh}(-) \\ \text { Fever } & 108(51.2) & 42(19.9) & 50(23.7) & 11(5.2) & 50(23.7) & 161(76.3) & 197(93.7) & 14(6.6) \\ \text { Cough } & 30(42.9) & 13(18.6) & 20(28.6) & 7(10) & 20(28.6) & 50(71.4) & 64(91.4) & 6(8.6) \\ \text { Dyspnea } & 34(38.6) & 16(18.2) & 27(30.7) & 11(12.5) & 27(30.7) & 61(69.3) & 84(95.5) & 4(4.5) \\ \text { Fatigue } & 33(48.5) & 10(14.7) & 19(27.9) & 6(8.8) & 18(28.1) & 46(71.9) & 65(95.6) & 3(4.4) \\ \text { Backache } & 32(48.5) & 12(18.2) & 21(31.8) & 1(1.5) & 21(32.3) & 44(67.7) & 61(92.4) & 5(7.6) \\ \text { Loss of Smell } & 49(41.5) & 25(21.2) & 38(32.2) & 6(32.2) & 37(31.6) & 80(68.4) & 110(93.2) & 8(6.8) \\ \text { Loss of Taste } & 40(57.1) & 7(10) & 16(22.9) & 7(10) & 16(22.9) & 54(77.4) & 64(91.4) & 6(8.6) \\ \text { Sore Throat } & 13(39.4) & 8(24.2) & 10(30.3) & 2(6.1) & 10(30.3) & 23(69.7) & 32(97) & 1(3) \\ \text { None } & 23(33.3) & 9(13) & 32(46.4) & 5(7.2) & 32(46.4) & 37(53.6) & 61(88.4) & 8(11.6)\end{array}$

Chi-square test analysis was performed

Table 4. Factors affecting development of infection in contacts

95\% C.I.for $\operatorname{EXP}(B)$

$\begin{array}{lcccc}\text { Fever } & \mathrm{p} & \operatorname{Exp}(\mathrm{B}) & \text { Lower } & \text { Upper } \\ \mathrm{Rh}(+) \text { Blood Group } & 0.000 & 0.475 & 0.313 & 0.721 \\ \text { Comorbid diseases } & 0.000 & 4.57 & 3.31 & 6.30\end{array}$

Binary logistic regression analysis was performed

\section{DISCUSSION}

$\mathrm{ABO}$ and $\mathrm{Rh}$ blood groups play a vital role during blood transfusion and in several clinical practices. Their relationship with infectious, non-infectious and cancerous diseases has widely been investigated and various studies have been performed on this issue (1114). Arac et al. reported in their study that the rate of $A$ blood group was higher in those infected with SARSCoV-2 infection compared with the normal healthy population (15). The rate of having A blood group is higher and the rate of having 0 blood group is lower in individuals who haveSARS-CoV-2infection (16). The prevalence of SARS-CoV-2 infection has been reported to be higher in Non-O blood groups (17). The data of this study were similar to the findings in literature. 
Torun et al. analyzed blood groups of 86,797 individuals between January 2008 and September 2010 in their study showing the prevalence of blood groups in general population. Of the blood samples, $88.2 \%(n=76,580)$ were Rh positive and $11.8 \%(n=10,217)$ were Rh negative. The prevalences of $A, O, B$, and $A B$ blood groups were $44 \%(n=$ $38,253), 33.3 \%(n=28,904), 16.2 \%(n=14,031)$, and $6.5 \%$ $(n=5,609)$ respectively $(18)$.

Since the study by Torun et al.was conducted in the same region as this study, our data were found to be similar to the general population. A study conducted in Diyarbakir province showed that the $R h(+)$ ratio of PCR-positive patients was higher compared with the general population (15). The general population was not evaluated in this study. The infected/source and contact persons who were in the quarantine process formed the sample of this study.One of the factors affecting the SARS-CoV-2 positivity of people in contact during the quarantine process is the state of $\mathrm{Rh}(+)$ blood type.

In addition, the rate of a blood group was proportionally higher and that of Non-O blood group was significantly higher in group 1 and 2 (SARS-CoV-2(+) patients). The rate of contacts in whom SARS-CoV-2infection developed in group 2 was high similarlyto that in literature in terms of $A$ and Non-O blood groups. This result suggests that the risk of developing SARS-CoV-2infection is high in $A$ and Non-A blood groups. In studies assessing the relationship between $\mathrm{Rh}$ blood groups and SARS-CoV2infection, the rate of Rh positive blood group was found significantly high. It was emphasized for Rh negative blood group that it could have a preventive effect against SARS-CoV-2(16,18). In this study, Rh positive blood group increased the risk of SARS-CoV-2infection, which suggests that $\mathrm{Rh}(-)$ blood group is preventive against SARS-CoV2.

ABO blood group may have an effect on symptoms inpatients with SARS-CoV2. Clinical symptoms of people with different blood types may be different after SARSCoV-2infection. In the study by Wu et al., fever and cough were more in A blood group according to the distribution of symptoms $(p<0.05$ and $p: 0.05$ respectively). Dyspnea was more in $A B$ blood group $(p<0.05)$. Fatigue and malaise were associated with $A$ and $O$ blood groups $(p<0.05)$ (19). In this study, fever, cough, dyspnea, and other symptoms were more in patients with $A$, Non-O and $\mathrm{Rh}(+)$ blood groups, which is consistent with the data in literature. It is considered that clinical presentation of SARS-CoV-2infection is more severe in patients with $\mathrm{A}$, Non-O and $\mathrm{Rh}(+)$ blood groups. In literature, there are studies investigating the effect of blood groups on clinical prognosis of patients. In the study by Juyi et al., the rate of hospitalization was higher in patients with $A$ blood groups in SARS-CoV-2infection and in another study, the rate of Rh positivity was reported to be higher in patients hospitalized in the intensive care unit (ICU) $(20,21)$. Our data are similar to findings in these studies. As individuals with $\mathrm{A}, \mathrm{Non}-\mathrm{O}$ and $\mathrm{Rh}(+)$ blood groups have more severe clinical course, they should be carefully followed up in terms of hospitalization.

There is no study revealing that there is a relationship between blood groups and pulmonary involvement (pneumonia) in SARS-CoV2. In this study, pneumonia was more in A, Non-O and Rh (+) blood groups, but there was no statistical relationship. In studies investigating the effect of blood groups on mortality in SARS-CoV2infection, while it was reported that Rh (-) blood group decreased the risk of mortality and intubation, no significant relationship was found among blood groups and intubation or the risk of SARS-CoV-2infection and mortality in some studies $(17,22,23)$. In this study, no relationship was found between mortality and blood groups. Other parameters such as having a comorbidity, smoking history and being a healthcare worker in SARSCoV-2infectionhave also been assessed in studies. The risk factors that have commonly been mentioned and studied in SARS-CoV-2infection are age, gender and comorbid diseases such as hypertension, diabetes mellitus and cardiovascular disease. It has been revealed in China and Italy that hypertension and cardiovascular diseases increase the mortality rates (25-27). Presence of a comorbid disease causes breathing problems in patients and increase in mortality rate (27). Comorbidity rates in patients who are hospitalized in the intensive care unit (ICU) or who are exitus have increased up to $90 \%$ (28). In this study, comorbidities were significantly more in group 1 including source patients, which is consistent with findings in literature. It is considered that the risk of SARS-CoV-2infection increases in individuals with a comorbidity.

In a study in Latium, Italy, although the prevalence of SARS-CoV-2was low among healthcare workers they were infected 34 times more often compared with the general population. This was because of the increased risk in the workplace (29). It was observed in this study that being a healthcare worker did not increase the risk of SARS-CoV-2infection. There are also studies in which smoking is another risk factor and individuals' status of being infected with SARS-CoV-2has been assessed. The results of a meta-analysis performed in China have revealed that active smoking does not increase the risk of progression to a serious disease in SARS-CoV2infection (30). In this study, findings on smoking were similar to those on non-smoking, which is consistent with the findings in literature.

\section{CONCLUSION}

The rate of developing the disease after contact with the infected patient was higher in individuals with Rh positive blood group. The prevalence of SARS-CoV-2infection was higher in $\mathrm{A}$ and Non-O blood groups. Clinical course was more severe in A, Non-O and Rh (+) blood groups. These individuals should be followed up more carefully, as their risk of being infected is higher. We think close follow-up of individuals especially with $\mathrm{Rh}$ positive blood group after contact with the infected person can decrease the 
risk of complication development.

Limitations of this study are as follows: As SARS-CoV-2 has emerged as a new infection source there are no sufficient studies on this subject and further studies are needed. Other limitations in this study are as follows: most of the individuals were tested with PCR only once and file scanning was performed and criteria for hospitalization changed according to the current conditions.

Financial disclosures: All authors report no financial interests or potential conflicts of interest.

Conflict of Interest: The authors declare that they have no competing interest.

Ethical approval: The approval of Erciyes University Medical Faculty Ethics Committee was obtained (Date: 02.12.2020; Decision No: 2020/615)

\section{REFERENCES}

1. Paules $\mathrm{Cl}$, Marston HD, Fauci AS. Coronavirus infectionsmore than just the common cold. JAMA. 2020;323:707-8.

2. Ksiazek TG, Erdman D, Goldsmith CS, et al. A novel coronavirus associated with severe acute respiratory syndrome. N Engl J Med. 2003;348:1953-66.

3. de Groot RJ, Baker SC, Baric RS, et al. Middle East respiratory syndrome coronavirus (MERS-CoV): announcement of the Coronavirus Study Group. J Virol. 2013;87:7790-2.

4. Zhu N, Zhang D, Wang W, et al. A novel coronavirus from patients with pneumonia in china, 2019. N Engl J Med. 2020;382:727-33.

5. Zhao J, Yang $\mathrm{Y}$, Huang $\mathrm{H}$, et al. Relationship between the ABO Blood Group and the COVID-19 Susceptibility. Clin Infect Dis. 2020; ciaa1150.

6. Avent ND, Reid ME. The Rh blood group system: a review. Blood. 2000;95:375-87.

7. Franchini M, Capra F, Targher G, et al. Relationship between ABO blood group and von Willebrand factor levels: from biology to clinical implications. Thromb J. 2007;5:14.

8. Franchini M, Favaloro EJ, Targher G, et al. ABO blood group, hypercoagulability, and cardiovascular and cancer risk. Crit Rev Clin Lab Sci. 2012;49:137-49.

9. Harris JB, Khan Al, LaRocque RC, et al. Blood group, immunity, and risk of infection with Vibrio cholerae in an area of endemicity. Infect Immun. 2005;73:7422-7.

10. Göker $H$, Aladağ Karakulak E, Demiroğlu $H$, et al. The effects of blood group types on the risk of COVID-19 infection and its clinical outcome. Turk J Med Sci. 2020;50:679-83.

11. Anstee DJ. The relationship between blood groups and disease. Blood. 2010;115:4635-43.

12. Cheng $Y$, Cheng $G$, Chui $C H$, et al. $A B O$ blood group and susceptibility to severe acute respiratory syndrome. JAMA. 2005;293:1450-1.

13. Cserti CM, Dzik WH. The ABO blood group system and Plasmodium falciparum malaria. Blood. 2007;1 10:2250-8.

14. Iodice $S$, Maisonneuve $P$, Botteri $E$, et al. ABO blood group and cancer. Eur J Cancer. 2010;46:3345-50.
15. Arac E, Solmaz IH, Akkoc $H$, et al. Association Between the Rh Blood Group and the Covid-19 Susceptibility. Int J Hematol Oncol. 2020;30:81-6.

16. Golinelli $D$, Boetto $E$, Maietti $E$, et al. The association between ABO blood group and SARS-CoV-2 infection: A metaanalysis. PLoS One. 2020;15:e0239508.

17. Zietz M, Zucker J, Tatonetti NP. Associations between blood type and COVID-19 infection, intubation, and death. Nat Commun. 2020;11:5761.

18. Torun YA, Kaynar LG, Karakükcü C, et al. ABO and Rh Blood Group Distribution in Kayseri Province, Turkey. Turk J Haematol. 2012;29:97-8.

19. Wu Y, Feng Z, Li P, et al. Relationship between ABO blood group distribution and clinical characteristics in patients with COVID-19. Clin Chim Acta. 2020;509:220-3.

20. Li J, Wang X, Chen J, et al. Association between ABO blood groups and risk of SARS-CoV-2 pneumonia. $\mathrm{Br} \mathrm{J}$ Haematol 2020;190:24-7.

21. Yaylacı $S$, Dheir $H$, Issever $K$, et al. The effect of abo and rh blood group antigens on admission to intensive care unit and mortality in patients with COVID-19 infection. Rev Assoc Med Bras. 2020;66:86-90.

22. Liu N, Zhang $T, M a L$, et al. The impact of $A B O$ blood group on COVID-19 infection risk and mortality: A systematic review and meta-analysis. Blood Rev. 2020;100785.

23. Latz CA, DeCarlo C, Boitano L, et al. Blood type and outcomes in patients with COVID-19. Ann Hematol. 2020;99:2113-8.

24. Wang D, Hu B, Hu C, et al. Clinical Characteristics of 138 Hospitalized Patients With 2019 Novel Coronavirus-Infected Pneumonia in Wuhan, China. JAMA. 2020;323:1061-9.

25. Chen N, Zhou M, Dong $X$, et al. Epidemiological and clinical characteristics of 99 cases of 2019 novel coronavirus pneumonia in Wuhan, China: a descriptive study. Lancet. 2020;395:507-13.

26. Onder G, Rezza G, Brusaferro S. Case-Fatality Rate and Characteristics of Patients Dying in Relation to COVID-19 in Italy. JAMA. 2020;323:1775-6.

27. Yang J, Zheng $Y$, Gou $X$, et al. Prevalence of comorbidities and its effects in patients infected with SARS-CoV-2: a systematic review and meta-analysis. Int $\mathrm{J}$ Infect Dis. 2020;94:91-5.

28. Espinosa OA, Zanetti ADS, Antunes EF et al. Prevalence of comorbidities in patients and mortality cases affected by SARS-CoV2: a systematic review and meta-analysis. Rev Inst Med Trop Sao Paulo. 2020;62:e43.

29. Lahner E, Dilaghi E, Prestigiacomo C, et al. Prevalence of Sars-Cov-2 Infection in Health Workers (HWs) and Diagnostic Test Performance: The Experience of a Teaching Hospital in Central Italy. Int J Environ Res Public Health. 2020;17:4417.

30. Lahner E, Dilaghi E, Prestigiacomo $C$, et al. Prevalence of Sars-Cov-2 Infection in Health Workers (HWs) and Diagnostic Test Performance: The Experience of a Teaching Hospital in Central Italy. Int J Environ Res Public Health. 2020;17:4417. 